\title{
Life History of Talorchestia deshayesii (Amphipoda, Talitridae) in the Ionian Sandy Beach (Southern Italy)
}

\author{
Ermelinda Prato*, Annunziata Trono and Francesca Biandolino \\ Consiglio Nazionale delle Ricerche - IAMC; Taranto; Via Roma 3; 74100, Taranto - Italy
}

\begin{abstract}
The population structure and reproductive biology of Talorchestia deshayesii (Audouin, 1826) on an exposed sandy beach in Taranto (Italy) was examined during one year cycle. Monthly surveys were performed from September 2002 to August 2003. Individuals were subdivided into sex, measured and abundance were calculated for each sampling. Abundance varied during the study period, with a marked decrease in winter. T. deshayesii, was found in a relative narrow zone near the sea in winter and summer while in spring and autumn the animals were widespread along the supralittoral. Reproduction occurred from February to November. The minimum average CL at the moment of recovery ranged from 0.22 to $0.28 \mathrm{~mm}$. The sex ratio was female biased. The females and males became distinguishable at $0.35 \mathrm{~mm}$ (corresponding to $4.5 \mathrm{~mm}$ of LT). The first time that females were observed ovigerous happened when they reached a size about $0.4 \mathrm{~mm}$ of $C L$. The males of $\mathrm{T}$. deshayesii grew larger than the females. The males reached a maximum CL of 1.05 (corresponding to $13.2 \mathrm{~mm}$ of LT), while females reached a CL of $1 \mathrm{~mm}$ (corresponding to $12.6 \mathrm{~mm}$ of LT). Mean length was the lowest in the summer months.

Maximum total length was $10.5 \mathrm{~mm}$ and the size at first reproduction for the females was $3.5 \mathrm{~mm}$ total length. T. deshayesii produced two generations per year. Fecundity varied from 3 to 20 eggs per female and mean fecundity varied through time.
\end{abstract}

Key words: Talorchestia deshayesii, biology, life cycle, Mediterranean, Ionian sea, sandy beach

\section{INTRODUCTION}

The littoral zone of sandy beaches are particularly well suited for biodiversity, dynamic and biogeographical studies due to their relative accessibility and frequency along the coastlines.

Most changes in the structure of sandy beaches communities seem to be the result from environmental change, food limitation and anthropic influence (Brown and McLachlan, 1990; Weslawski et al., 2000; Marques et al., 2003). These changes are important to evaluate how the organisms can adapt themselves to environmental and human-induced changes, foreseeing a sustainable use of beach environments.

Talitrid amphipods constitute one the most important group in sandy beach fauna (Dahl, 1946; Wildish, 1988; Mc Lachlan and Jaramillo, 1995).

Their ecological relevance is justified from the great quantity of existing literature. Many authors have described their spatial distribution and oriented movements in sandy beaches (Borgioli et al., 1999; Scapini et al., 1999; Scapini and Quochi, 1992); their behavioural strategies (Fallaci et al., 1999); and their use as an environmental indicator (Rainbow et al., 1989; Moore et al., 1991;

\footnotetext{
Author for correspondence: linda.prato@iamc.cnr.it
} 
Weslawski et al., 1999; Fialkowski et al., 2000). However, there are few studies on thetalitrids'population biology (Williams, 1978; Elkaïm et al., 1985; Van Senus, 1988 Jones and Wigham, 1993; Persson, 1999)

The talitrid amphipod Talorchestia deshayesii (Audouin, 1826) is a sandhopper, which lives near the supralittoral level of sandy beaches under seaweed. It is a frequently recorded species along the European coasts: in the Mediterranean sea (Dahl, 1946); Baltic sea (Caspers, 1951) and in the North sea (Kalbrink, 1969). There are some short notes on T. deshayesii's ecology (Kalbrink, 1969) but no studies on its biology.

The knowledge of population structure is important for the study of environmental and faunistic changes caused by the anthropogenic interference or by natural fluctuations.

Since the population structure is still quite unexplored on Mediterranean beaches, an Italian population of Talorchestia deshayesii, was studied in order to investigate the temporal and spatial changes in abundance, population structure and reproductive features.

Torre Colimena sandy beach is located along the Ionian coast (Southern Italy). In recent years, this beach was forced to a human impact due to an intense tourism during the summer months, which has seriously affected the equilibrium of environment. The underlying purpose of this study was to examine the life history traits and population dynamics of $T$. deshayesii along Torre Colimena beach.

\section{MATERIALS AND METHODS}

The Torre Colimena sandy beach $\left(40^{\circ} 15^{\prime} 51^{\prime \prime} \mathrm{N}\right.$; $17^{\circ} 43^{\prime} 51^{\prime \prime}$ E) located in the Southern Apulia (Gulf of Taranto, Ionian sea) (Fig. 1) is an exposed beach, with a supralittoral zone of about $15 \mathrm{~m}$ wide, with no vegetation.

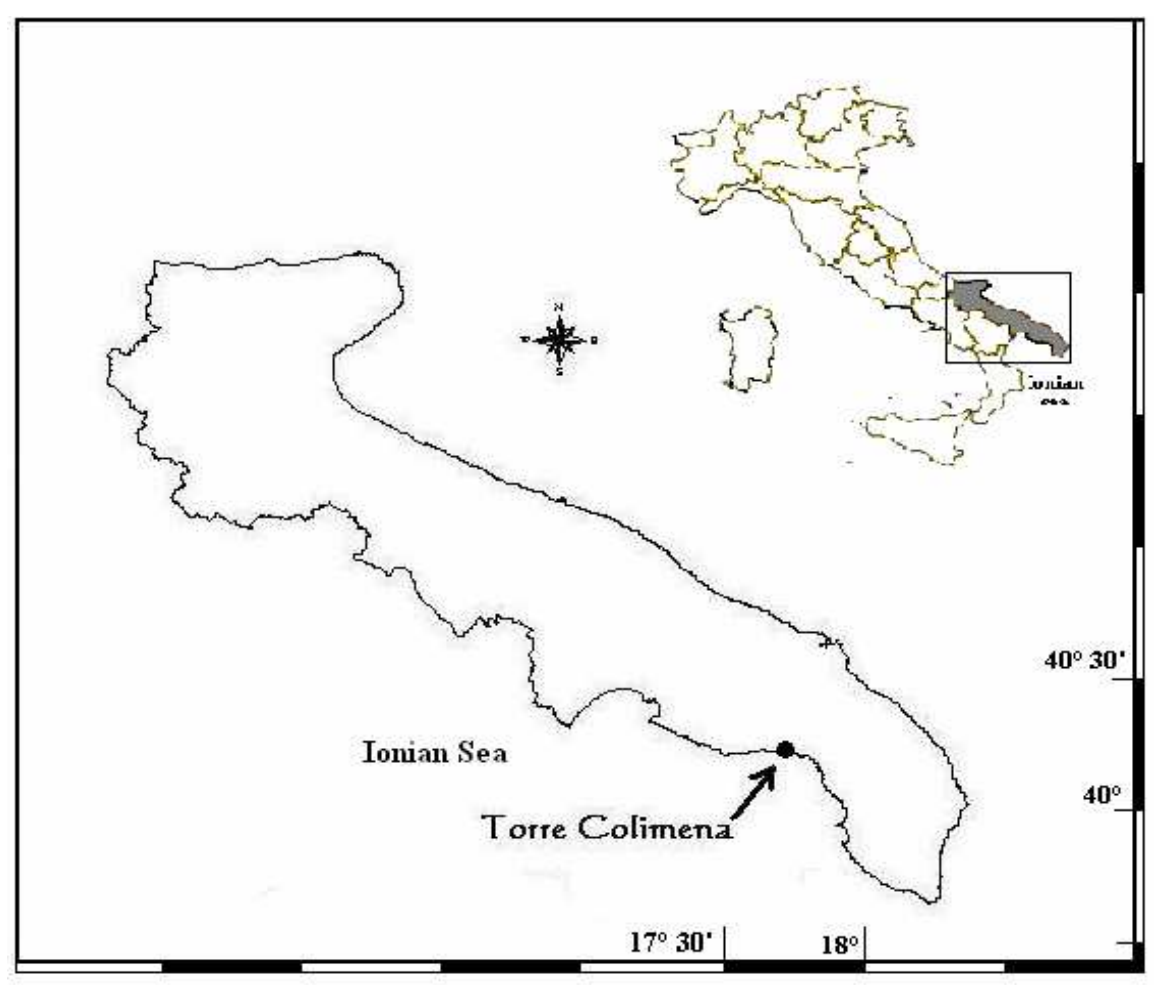

Figure 1 - Sampling site in Torre Colimena sandy beaches. 
This area may be inundated and occasionally the waves reach the dunes, during the sea storms, with deposition of abundant amount of the phanerogam plant Posidonia oceanica and animals such as molluscs, crustaceans, etc. The dune is characterised by typical pioneer plants, such as Ammophila arenaria, Euphorbia paralis and Cakile maritime; the retrodunal area is characterised by the Mediterranean maquis.

The sediment was classified as medium sand with a mean grain size between 0.250 and $0.500 \mathrm{~mm}$ (Wentworth scale) (Brown and Mc Lachlan, 1990). Sandhoppers were collected during one year from September 2002 to August 2003

Three replicates for each samples were taken at regular intervals along four transects (spaced approximately $4 \mathrm{~m}$ ) from the upper limit of swash zone up to the base of the dune vegetation. Twenty sampling stations were chosen for each transect, beginning at the base of the dunes and continuing at $0.5 \mathrm{~m}$ intervals in a seaward direction.

Specimens of $T$. deshayesii were collected by a square metal box ( $25 \times 25 \mathrm{~cm}, 15 \mathrm{~cm}$ depth). The sand was sieved through $750 \mu \mathrm{m}$ mesh size, which retained all the individuals, including newly hatched juveniles. The amphipods were transported alive to the laboratory, where they were isolated from the other species of animals, and then were fixed in $4 \%$ formalin.

To investigate the influence of physicochemical factors on the $T$. deshayesii population of each sampling station, all the superficial debris was collected to estimate the organic matter (potential food, $\mathrm{mg} \mathrm{m}^{-2}$ ) and sediment moisture. The organic matter was determined as ash-free dry weight (AFDW) after combustion at $550^{\circ}$ during $12 \mathrm{~h}$. Sediment moisture, was calculated as the difference between the initial weight of sediment samples and its dry weight after $24 \mathrm{~h}$ at $60^{\circ} \mathrm{C}$.

Metereological data during the study period were obtained from the nearest weather station, including average daily precipitations and temperatures, relative humidity, wind velocity, wave heigth.

In the laboratory, amphipods were counted, measured and sexed. Cephalic length (CL) was used instead of the total length (TL), in view of the difficulty in measuring the amphipod's recurved body. Cephalic length was measured from the anterior end of the rostrum to the posterior margin, using binocular microscopes, equipped with micrometrical ocular lens and calibrated with objective micrometers. Each month, it was calculated the total number of the individuals collected in each quantitative sample $\mathrm{x} \mathrm{m}^{-2}$ was calculated.

The relation between TL and CL was previously determined in a sample of 120 animals. This was described by the following linear regression equation:

$$
\mathrm{TL}=12.566 \mathrm{CL}+0.0495 ; \mathrm{R}^{2}=0.892
$$

According to Gómez and Defeo (1999), the sandhoppers were classified as juveniles, female or male. Sexual dimorphism was only evident in the adult animals: male sexually mature was determined by the appearance of an enlarged propodus on the second gnatopod and by the presence of the penial papillae; female was determined by the appearance, presence and condition of oostegites. Immature females had oostegites lacking setae; ovigerous females had fully developed setose oostegites and eggs in the brood pouch. Animals without these characteristics were considered to be juveniles.

Contents of the brood pouch were removed and counted. The relationship between the number of eggs and the cephalic length of females was determined by linear regression analysis.

The number of males, females and juveniles was expressed as the percentage of the total number of individuals. The sex ratio $(\phi / \delta)$ of the population was estimated and deviations from unity were assessed by a $\chi^{2}$ test.

The population was analyzed by the graphical analysis of polymodal frequency distributions (Harding, 1949).

\section{RESULTS}

The average values of the environmental parameters monitored in Torre Colimena during the whole study period are summarised in Table 1. A positive correlation between the number of juveniles in the samples and sediment moisture was found, which indicated that juveniles are more sensitive to dehydration $(r=0.60 \mathrm{p}<0.05)$. No other significant correlations were found between population features and environmental factors. Talorchestia deshayesii is present throughout the year along Torre Columena sandy beach. The lowest densities were observed in the winter months followed by a rapid increase on spring, when the maximum is attained in March and April (1728 and 1621 ind./m² respectively) (Fig.2). 


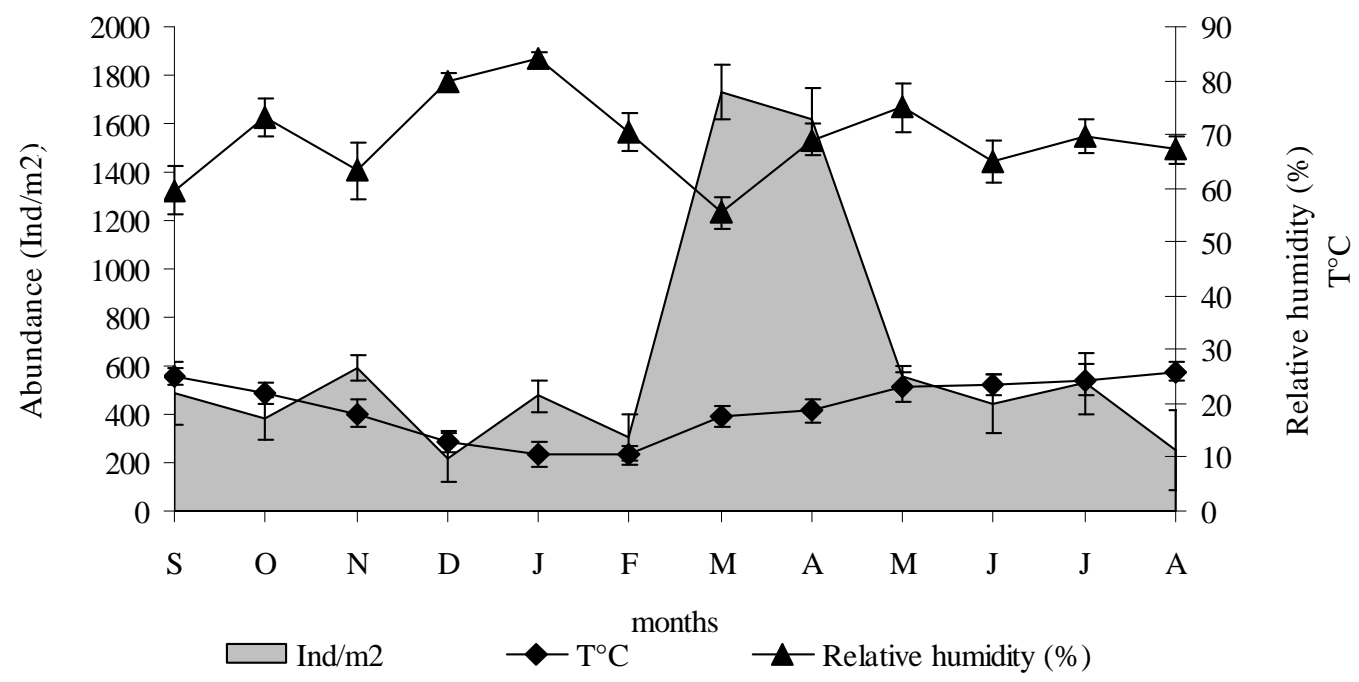

Figure 2 - Monthly fluctuation of average and S.D. values of temperature, relative humidity and density (ind $/ \mathrm{m}^{2}$ ) during the sampling period (September 2002 to August 2003).

Table 1 - Average daily values and standard deviation (S.D.) of physicochemical factors at Torre Colimena (Ionian Sea) during the study period (September 2002 to August 2003).

\begin{tabular}{ccccccccccc}
\hline & $\begin{array}{c}\text { Temperature } \\
{ }^{\circ} \mathbf{C}\end{array}$ & S.D. & $\begin{array}{c}\text { Relative } \\
\text { umidity (\%) }\end{array}$ & S.D. & $\begin{array}{c}\text { Sediment } \\
\text { moisture }(\%)\end{array}$ & S.D. & $\begin{array}{c}\text { Organic } \\
\text { matter }(\%)\end{array}$ & S.D. & $\begin{array}{c}\text { Detritus } \\
(\mathbf{g} / \mathbf{m})\end{array}$ & S.D. \\
\hline $\mathrm{S}$ & 25 & 1.5 & 59.5 & 4.5 & 2.3 & 1.85 & 0.35 & 0.2 & 3.7 & 0.4 \\
$\mathrm{O}$ & 22 & 2 & 73.2 & 3.4 & 1.8 & 1 & 0.8 & 0.5 & 4.6 & 1.6 \\
$\mathrm{~N}$ & 18.1 & 2.5 & 63.2 & 5.2 & 1.1 & 1.6 & 0.6 & 0.3 & 2.6 & 1 \\
$\mathrm{D}$ & 13 & 2 & 80 & 1.3 & 0.9 & 1.3 & 0.4 & 0.2 & 4.6 & 3.2 \\
$\mathrm{~J}$ & 10.6 & 2.5 & 84 & 1.1 & 0.6 & 1.2 & 0.87 & 0.2 & 6.6 & 3.8 \\
$\mathrm{~F}$ & 10.5 & 1.7 & 70.5 & 3.6 & 2.3 & 2.6 & 1.6 & 0.8 & 1.8 & 0.5 \\
$\mathrm{M}$ & 17.7 & 1.9 & 55.5 & 3 & 5.3 & 0.9 & 1.1 & 0.5 & 3.6 & 0.8 \\
$\mathrm{~A}$ & 18.7 & 2.2 & 69 & 2.9 & 0.8 & 0.8 & 0.66 & 0.5 & 3.8 & 1.1 \\
$\mathrm{M}$ & 23 & 2.7 & 75 & 4.5 & 0.5 & 0.2 & 0.78 & 1 & 7.5 & 1.8 \\
$\mathrm{~J}$ & 23.6 & 2 & 65 & 4 & 0.3 & 0.3 & 0.56 & 0.3 & 4.2 & 2 \\
$\mathrm{~J}$ & 24.4 & 3 & 69.6 & 3 & 2.2 & 0.4 & 0.45 & 0.4 & 2.5 & 0.2 \\
$\mathrm{~A}$ & 25.9 & 1.8 & 67.2 & 2.5 & 2.2 & 1 & 0.25 & 0.1 & 4 & 1.5 \\
\hline
\end{tabular}

The horizontal distribution of $T$. deshayesii was similar during the same season, in particular in the winter and summer, the animals were present in a relative narrow zone near the sea, while in the spring and autumn the animals were widespread along the supralittoral, but they never reached the dune (except in November during a sea storm). The levels near the sea were the most populated (Fig. 3). 


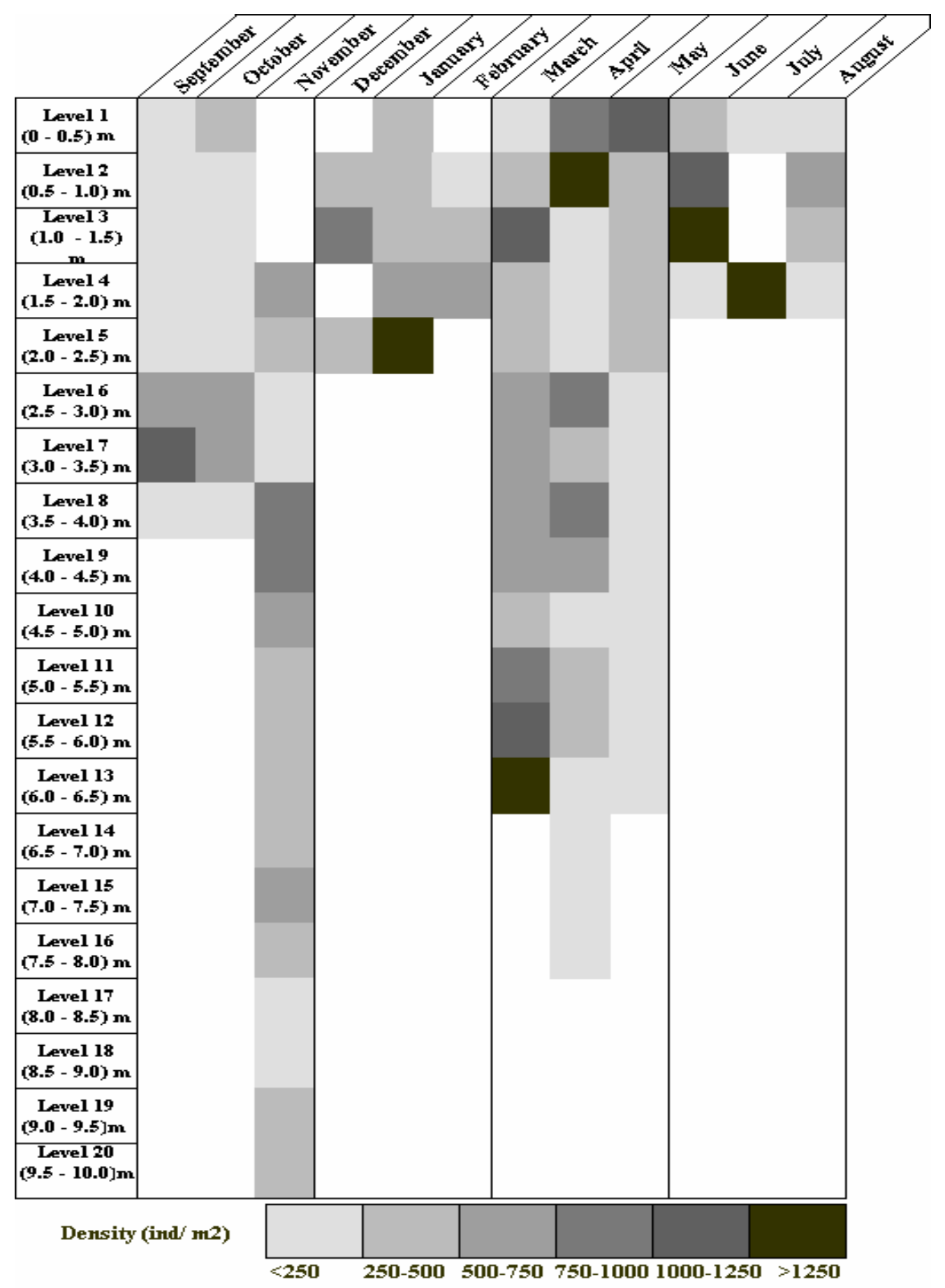

Figure 3 - Monthly determination of horizontal spatial distribution of Talorchestia deshayesii.

The occurrence of ovigerous females and the presence of juveniles in the population allowed the determination of the reproductive period. Ovigerous females were found at every sampling date, showing higher values in the autumn and spring, reaching a maximum value of $54 \%$ in June. Differences in recruitment of juveniles in the population were observed, with a peak in February and another one in August. The proportion of juveniles present in the population declined continuously from November to January, associated with a reduction in the number of the ovigerous female, and from March to June (Fig. 4). 


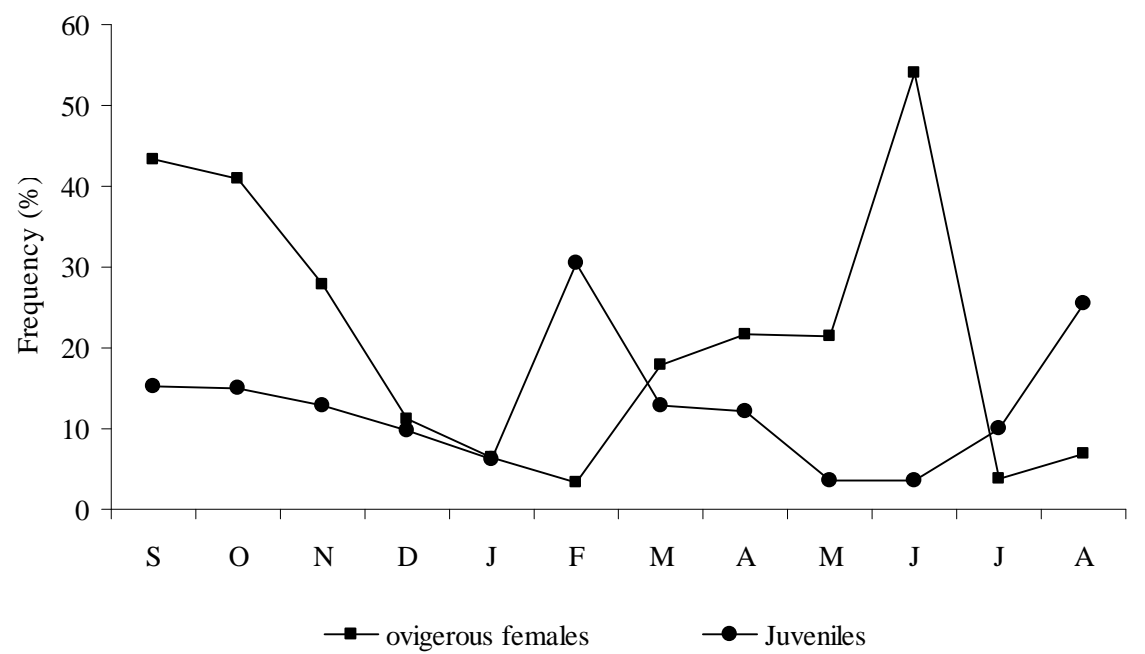

Figure 4 - Frequency of ovigerous females and frequency of juveniles.

The lowest frequency of ovigerous females were observed during the summer months. This seemed to be linked to the fastest developing individuals, advancing the process of sexual maturation. The monthly variation of immature, mature and ovigerous females is represented in Fig. 5. Relationships were found between ovigerous vs mature females and mature vs immature females but no relationship between ovigerous vs immature females (Tab.2).

Table 2 - Correlation equations linking the number of mature, ovigerous and immature females.

\begin{tabular}{lcccc}
\hline & Equations & r & p-values & $\mathbf{N}$ \\
\hline Mature vs Ovigerous females & $\mathrm{y}=6.4145+0.3654 \mathrm{x}$ & 0.55 & $<0.05$ & 12 \\
Immature vs Mature females & $\mathrm{y}=3.3227+0.561 \mathrm{x}$ & 0.80 & $<' 0.005$ & 12 \\
Immature vs Ovigerous females & $\mathrm{y}=8.0256+0.1934 \mathrm{x}$ & 0.39 & $>0.05$ & 12 \\
\hline
\end{tabular}

$\mathrm{r}=$ correlation coefficient; $\mathrm{N}=$ number of observations.

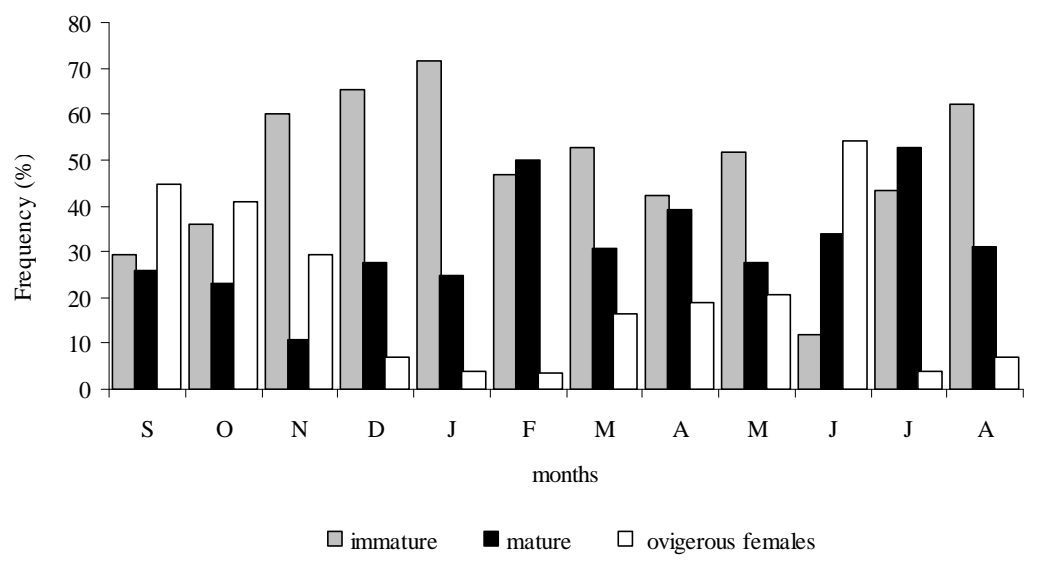

Figure 5 - Monthly variation of the frequency of mature, immature and ovigerous females. 
The minimum size of an ovigerous female was 5.1 $\mathrm{mm}$ with 3 eggs, whereas the maximum brood size observed was 14 for a female of $10.1 \mathrm{~mm}$. Fig. 6 showed the relationship between the number of eggs per brood and females cephalic length, which was statistically significant and the equation obtained was:

$$
\mathrm{y}=6.0683 \mathrm{x}+1.8352 \mathrm{R}^{2}=0.8149
$$

The males and females became distinguishable at $0.35 \mathrm{~mm}$ (corresponding to $4.5 \mathrm{~mm}$ of LT). The males of $T$. deshayesii grew larger than the females. However, fluctuations in size exhibited similar seasonality in females and males: mean lengths of both were maximal in March: males reaching a maximum cephalic length of 1.05 (corresponding to $13.2 \mathrm{~mm}$ of LT), while females reaching a cephalic length of $1 \mathrm{~mm}$ (corresponding to $12.6 \mathrm{~mm}$ ). Mean length were the lowest in the summer months. In addition to these samplings, a male with a LT of $15.3 \mathrm{~mm}$ was collected at the study site.

The sex ratio fluctuated throughout the study period and has been biased in favour of females with the exception of December. The mean value in this study was 1:1.87 ( \pm 0.1 standard error) (Fig. 7). Results of $\chi^{2}$ test in deviation of the sex ratio $(\chi 2=49.8 ; \quad \mathrm{df}=10 \mathrm{p}<0.001)$ confirm the significance of the deviation from 1:1.

The population was analysed by the size frequency polymodal distribution for recognizable cohorts (Figs 8-9). During the study period, eight-nine new cohorts could be recognised from September to August. An initial recruitment occurred in autumn, followed by a peak in late winter and a decrease during the early summer months. Four cohorts could be identified at the first sampling date, for which a sufficient number of individuals was found to perform the modal analysis.

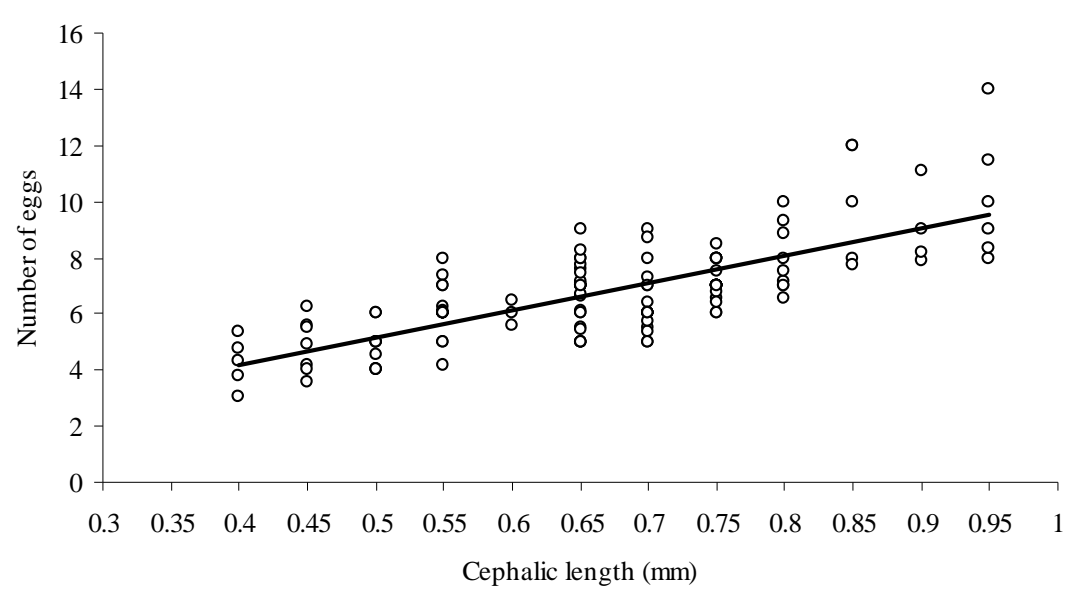

Figure 6 - Relationship between the number of eggs per brood and females cephalic length (mm).

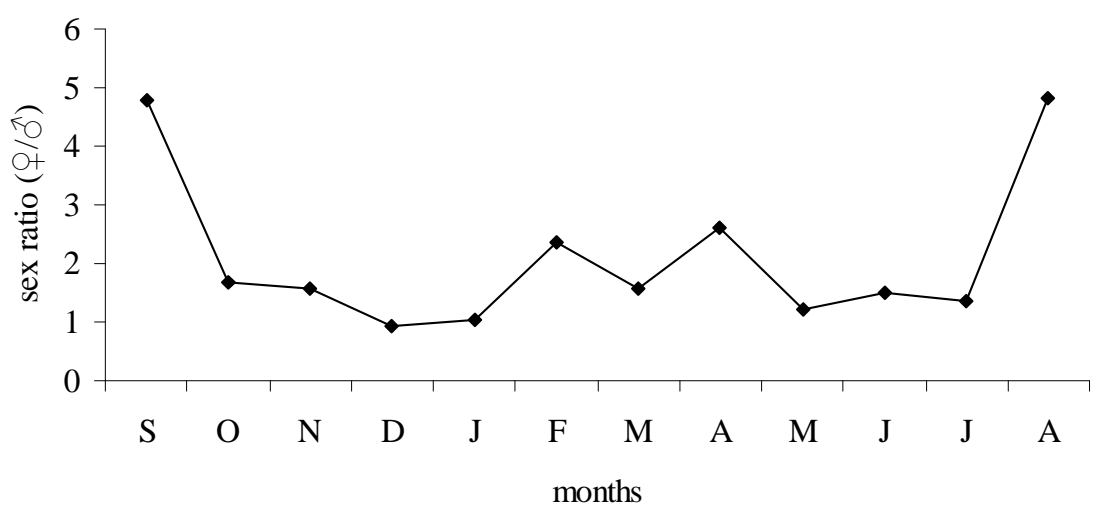

Figure 7 - Monthly variation in the sex ratio of Talorchestia deshayesii. 

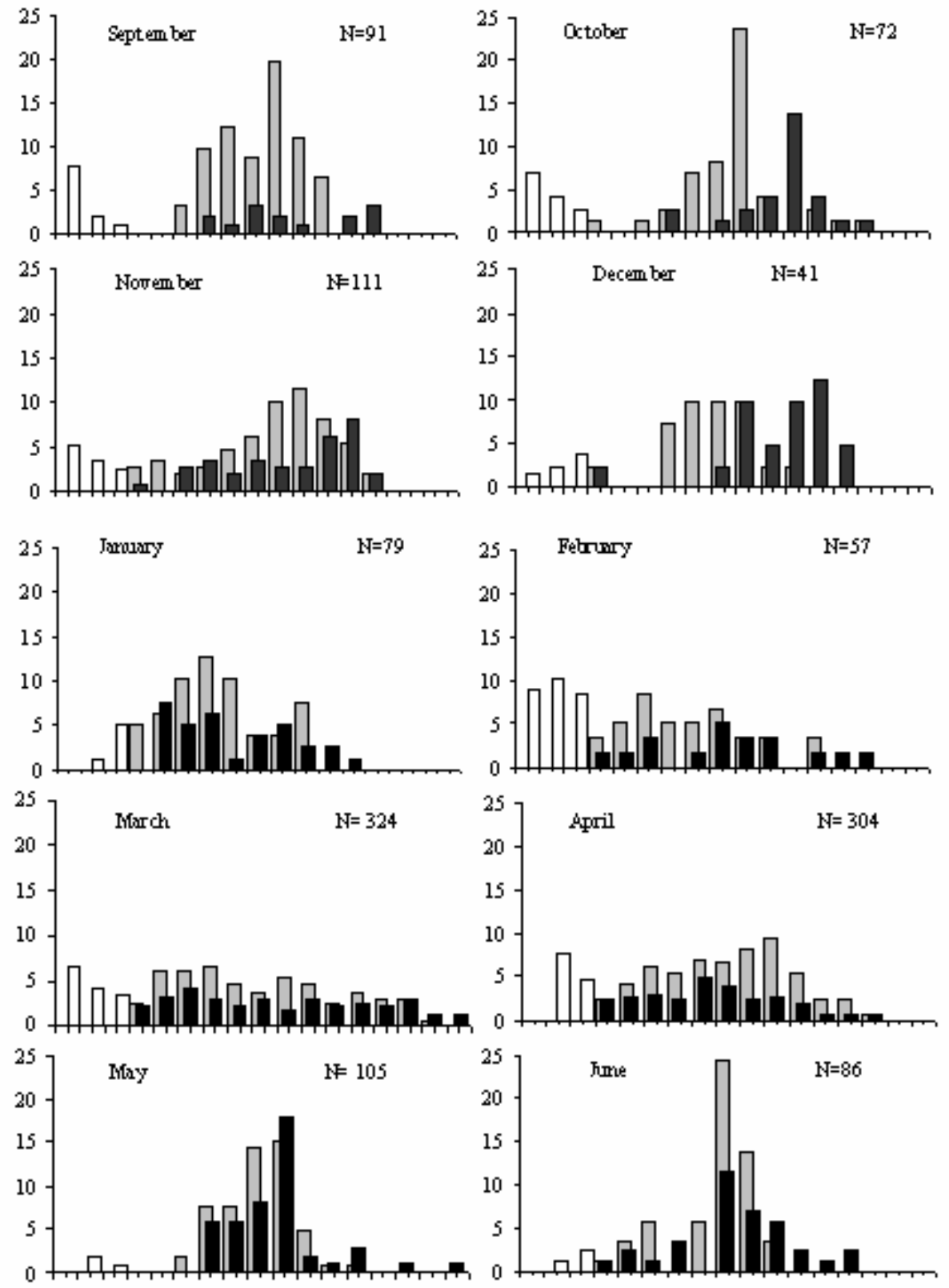

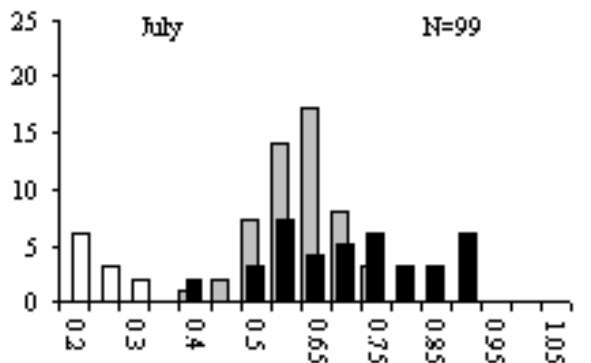

Cephalis kngth imm)

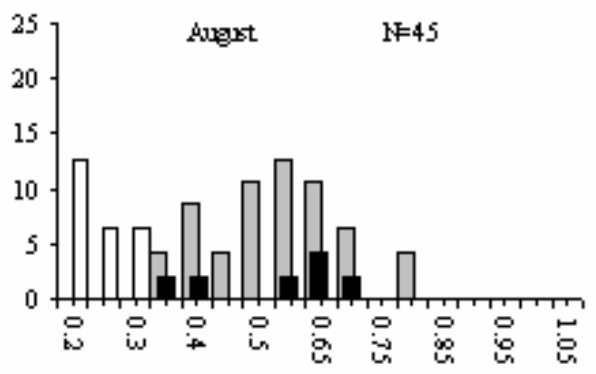

Cephalis length (mm)

$\square \%$ Juv.

Figure 8 - Size frequency distributions of the $T$. deshayesii population. $\mathrm{n}^{\circ}=$ Number of individuals. 


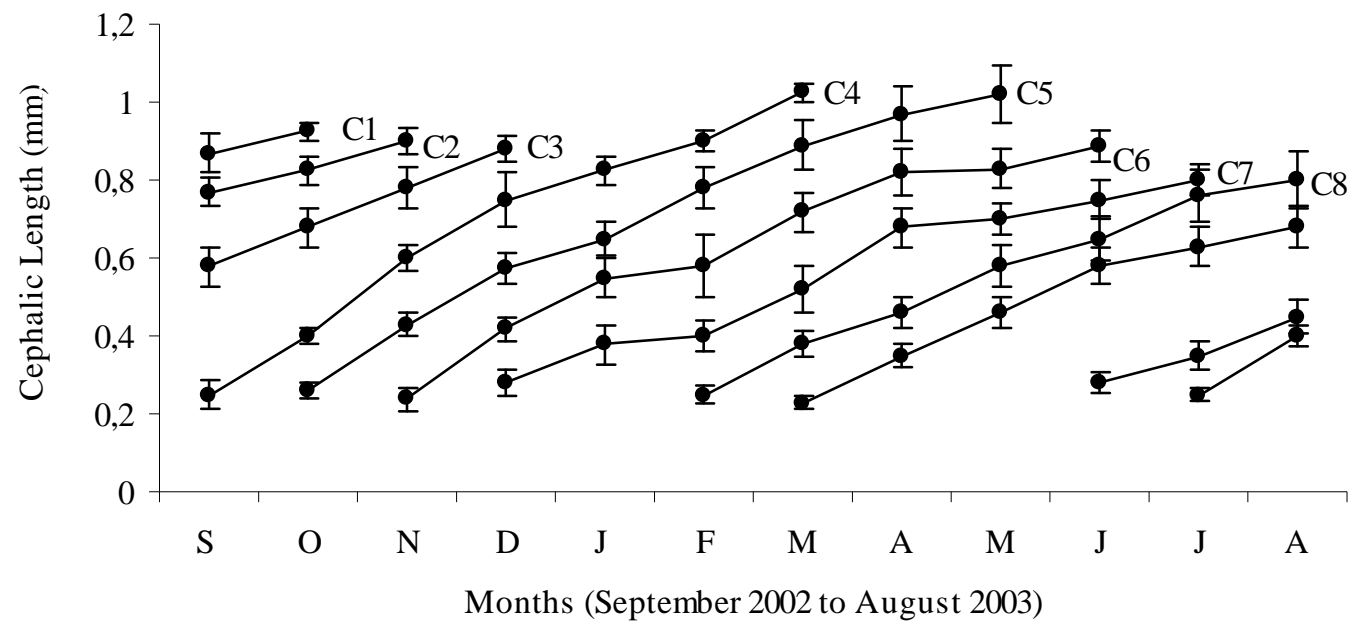

Figure 9 - Development in time of the population of $T$. deshayesii; dots = mean body length; bar lines $=$ standard deviation.

Taking into account the average body length at the time of the detection, cohort $\mathrm{C} 4$ was assumed as new born.

Seven new cohorts were identified during the next eleven months. The minimum average $C L$ at the time of recovery ranged from 0.22 to $0.28 \mathrm{~mm}$. Considering the disappearance of cohorts, life span was estimated at 6-8 months. Cohorts born in spring reproduce in same season, but live less and donot survive the winter. The longer life spans were observed in cohorts born in autumn, which have over-wintered and lived for a longer time.

\section{DISCUSSION}

In Torre Colimena sandy beach Talorchestia deshayesii was a dominant species in wrack beds of Posidonia and seemed to have an aggregated distribution pattern (personal observations). This was consistent with results from other authors: Marques et al. (2003) on Talitrus saltator and Mardsen (1991) on Talorchestia quoyana. They stated that an aggregate distribution pattern is often evident at small spatial scales (order of $0.25 \mathrm{~m}^{-2}$ ) and is not appraisable at large scales.

The correlation between juveniles and sediment moisture was not surprising, since smaller individuals generally lost water more rapidly than larger ones. Williams (1995), Tsubokura et al. (1997) and Fallaci et al. (2003) reported that juveniles occurred lower down on the shore, compared to the adults during the entire year and also in closer association with fresh wrack deposits. The reduction in the population density, during winter months was probably a response to the environmental constraints that might determine their migration and the displacement from the burrow zone into deeper layers where they found stable conditions. The occurrence of $T$. deshayesii on the beach showed that in summer and winter period, the animals remained close to the water line and retreated from the shoreline during the spring and autumn. Several explanations were proposed about the zonation patterns of different amphipods: age of animals, climatic conditions, sex of the individuals (Fallaci et al., 2003).

Seasonal variations in zonation pattern across the beach have been described in a number of talitrids such as Talorchestia quoyana (Marsden, 1991) $T$. capensis (van Senus and Mc Lachlan, 1986), $T$. brito (Gonçalves et al., 2003), Talitrus saltator (Williams 1995) Trinorchestia trinitatis (Tsubokura et al., 1997). These indicated that the talitrids tended to reduce the influence of unsuitable conditions, such as extreme temperature and desiccation by changing their horizontal distribution patterns. In this study, the reproductive period was long enough, since the ovigerous females were always present throughout the year and the recruitment was registered from February to November. Juveniles born in AugustSeptember represented the starting point of the overwintering generation, which grew during the 
colder months, reaching larger sizes in MarchApril. Those born in March represented the summer generation.

Although these data represented the only available information on this species'annual pattern of reproduction, it was known that in amphipods there was a geographical pattern.

High latitude amphipods are characterized by a shorter recruitment period that becomes longer in decreasing latitude (Gonçalves et al., 2003). Talorchestia brito reproduces from June to September in Netherlands (Vader, 1970), from March to October in SW France (Lagardère, 1966), February to September in Portugal and in Tunisia from March to November (Gonçalves et al., 2003). Bregazzi and Naylor (1972) reported that for Talitrus saltator the effects of seasonal changes in temperature and photoperiod could affect the gonadal maturation and duration of the reproductive period. This was also observed for other talitrid species: Orchestia mediterranea reproduced from April to October in Great Britain, from March to November in France and throughout the year in the Marocco coast (Elkaïm et al., 1985). Although Gaston and Spicer (1998) underlined that ecologists should proceed with caution when attempting to make generalisations about the physiology of the species based on studies of a single population. The number of embryos produced per female increased with females size. Size at maturity was an important life-history parameter: $T$. deshayesii females with setose oostegites were found at $0.35 \mathrm{~mm}$ of $\mathrm{CL}$ and the first time that females were observed ovigerous happened when they reached a size about $0.4 \mathrm{~mm}$ of CL.

During a large part of this study period, the population of $T$. deshayesii showed a sex ratio favourable to the females. In talitrid, it was usual that the females were more numerous than males, e.g. in O. gammarellus (Jones and Wigham, 1993; Persson, 1999); Pseudorchestia brasiliensis (Cardoso and Veloso, 1996), T. saltator (Williams, 1978), and T. capensis (Van Senus, 1988). Gonçalves et al. (2003) found a sex ratio different for two populations of $T$. brito, a sex ratio male biased for a population of the Portuguese coast and a population dominated by the females in Tunisia. Watt (1994) showed that photoperiod influenced the sex ratio of Gammarus duebeni, with the preponderance of the males, when exposed to long days, and preponderance of females on exposure to short days. Skewed sex ratios may be affected by the factors dependent on life cycle, such as the different mortality, longevity and growth rate between sexes (Hamilton, 1967; Wenner, 1972).

Talorchestia deshayesii's life span has not been examined before. In this study, the 5-8 months life expectancy fitted the pattern known from other talitrids: 6-7 months for a Portuguese population of Talitrus saltator and 5-9 months for the Tunisian one (Marques et al., 2003); 6-9 months for an Atlantic population of Talorchestia brito and 5-8 months for the Mediterranean one (Gonçalves et al., 2003); 5-9 months for a Maroccan population of Orchestia mediterranea (Elkaïm et al., 1985) and 12 months for Orchestia gammarellus in the British Isles (Jones and Wigham, 1993).

Talorchestia deshayesii produced two generations per year, in autumn and spring. Juveniles born in autumn represented the starting point of the overwintering generation, which grew during the colder months, reaching larger sizes in MarchApril.

The results shown here agreed with the life history variations in Talitridae and gave new data on the species, since the biological and ecological information on this species was insufficient, especially concerning the populations from Southern Italy coastal areas.

\section{ACKNOWLEDGEMENTS}

We thank Ms Maria Filippi for revising the English text.

\section{REFERENCES}

Borgioli, C.; Martelli, L.; Porri, F.; D'Elia, A.; Marchetti, G.M. and Scapini, F. (1999), Orientation in Talitrus saltator (Montagu): trends in intrapopulation variability related to environmental and intrinsic factors. J. Exp. Mar. Biol. Ecol., 238, 29-47.

Bregazzi P. K. and Naylor, E. (1972), .The locomotor activity rhythm of Talitrus saltator (Montagu) (Crustacea, Amphipoda). J. Exp. Mar. Biol. Ecol., 57, 375-391.

Brown, A. C. and Mc Lachlan, A. (1990), Ecology of sandy shores . Elsevier Sciences. Amsterdam. The Netherlands: 328pp.

Cardoso, R. S. and Veloso, V. G. (1996), Population biology and secondary production of the sandhopper 
Pseudorchestia brasiliensis (Amphi-poda: Talitridae) at Prainha beach, Brazil. Mar. Ecol. Progr. Series. 142, 11-119.

Caspers, H. (1951), Biozönotische Unter-suchungen über die Strandarthropoden im Bulgarischem Küstenbereich des Schwarzen Meeres. Hydrobiol., 3, 131-193.

Dahl, E. (1946), The Amphipoda of the Sound. Part Iterrestial amphipoda. Undersökningar over Oresund 29. Kgl. Fys. Sällsk. Handl. N.F. 57, 1-52.

Elkaïm, B.; Irlinger, J. P. and Pichard, S. (1985), Dynamique de la population d'Orchestia mediterranea L. (Crustacea, Amphipoda) dans l'estuaire du bou Regreg (Marocco). Canad. J. Zool., 63, 2800-2809.

Fallaci, M.; Aloia, A.; Audoglio, M.; Colombini, I.; Scapini, F. and Chelazzi, L. (1999), Differences in behavioural strategies between two sympatric talitrids (Amphipoda) inhabiting an exposed sandy beach of the French Atlantic. Coast. Estuar. Coast. Shel. Sci., 48, 469-482.

Fallaci, M.; Colombini, I.; Lagar, M.; Scapini, F. and Chelazzi, L. (2003), Distribution patterns of different age classes and sexes in a Tyrrehenian population of Talitrus saltator (Montagu). Mar. Biol., 142, 101110.

Fialkowski, W.; Rainbow, P. S.; Fialkowski, E. and D. B. Smith, D. B. (2000), Biomonitoring of trace metals along the Baltic coast of Poland using the sandhopper Talitrus saltator (Montagu) (Crustacea, Amphipoda). Ophelia, 52, 183-192.

Gaston, K. J. and Spicer, J. J. (1998), Do upper thermal tolerances differ geographically separated populations of the beachflea Orchestia gammarellus (Crustacea: Amphipoda). Journal of Experimental Marine Biology and Ecology, 229, 265-276.

Gómes, J. and Defeo, O. (1999), Life history of the sandhopper Pseudorchestoides brasiliensis (Amphipoda) in sandy beaches with contrasting morphodynamics. Marine Ecology Progress Series, 182, 209-220.

Gonçalves, S. C.; Marques, J. C.; Pardal, M. A.; Bouslama, M. F.; El Gtari, M. and CharfiChikhrouha, F.; (2003), Comparison of the biology, dynamics, and secondary production of Talorchestia brito (Amphipoda, Talitridae) in Atlantic (Portugal) and Mediterranean (Tunisia) populations. Estuar. Coast. Shelf Sci., 58, 901-916.

Hamilton, W. O. (1967), Extraordinary sex ratio. Scienc,. 156, 77-488.

Harding, J. P. (1949), The use of probability paper for the graphical analysis of polymodal frequency distributions. J. Mar.Biol. Ass. U. K., 28, 141-153.

Jones, M. B. and Wigham, G. D. (1993), Reproductive biology of Orchestia gammarellus (Crustacea: Amphipoda) living in a seawage treatment works. $J$. Mar.Biol. Ass. U. K., 73, 405-416.
Karlbrink, F. (1969), Distribution and dispersal of Talitridae (Amphipoda) in southern Sweden. Oikos, 20, 327-334.

Lagardère, J. P. (1966), Recherches sur la biologie et l'écologie de la macrofaune des substrats meubles de la côte des Landes et de la côte Basque. Bull. Centr. Etudes Recher. Scient. Biarritz, 6, 143-209.

Marques, J. C.; Gonçalves, S. C.; Pardal, M. A.; Chelazzi, L.; Colombini, I.; Fallaci, M.; Bouslama, M. F.; El Gtari, M.; Charfi-Cheikhrouha, F. and Scapini, F. (2003), Comparison of Talitrus saltator (Amphipoda, Talitridae) biology, dynamics and secondary production in Atlantic (Portugal) and Mediterranean (Italy and Tunisia) populations. Est. Coast. Shelf Sci., 58, 127-148.

Marsden, I. D. (1991), Kelp-sandhopper interactions on a sand beach in New Zeland. II Population dynamics of Talorchestia quoyana (Milne-Edwards). J. Exp. Mar. Biol. Ecol., 152, 75-90.

Mc Lachlan, A. and Jaramillo, E. (1995), Zonation on sandy beaches. Oceanogr. Mar. Biol. Ann. Rev. 33, 305-335.

Moore, P. G.; Rainbow, P. S. and Haynes, E. (1991), The sandhopper Orchestia gammarellus (Crustacea: Amphipoda) as a biomonitor for copper and zinc: North Sea trials. The Science of the Total Environment, 106, 221-238.

Persson, L. E. (1999), Growth and reproduction in two brackish water population of Orchestia gammarellus (Amphipoda: Talitridae) in the Baltic: J. Crust. Biol., 19, 53.59.

Rainbow, P. S.; Moore, P. G. and Watson, D. (1989), Talitrid amphipods (Crustacea) as biomonitors for copper and zinc. Eust. Coast. Shelf Sci., 28, 567-582.

Scapini, F. and Fasinella, D. (1990), Genetic determination and plasticity in the sun orientation of natural populations of Talitrus saltator. Mar. Biol., 107, 141-145.

Scapini, F. and Quochi, G. (1992), Orientation in sandhopper from Italian populations: have they magnetic orientation ability? Boll. Zool., 59, 437-442.

Scapini, F.; Porri, F.; Borgioli, C. and Martelli, L. (1999), Solar orientation of adult and laboratory-born juvenile sandhoppers: inter- and intra-population variation. J. Exp. Mar. Biol. Ecol., 238, 107-126.

Tsubokura, T.; Goshima, S. and Nakao, S. (1997), Seasonal horizontal and vertical distribution patterns of the supralittoral amphipod Trinorchestia trinitatis in relation to environmental variables. J. Crust. Biol., 17, 674-686.

Vader, W. (1970), Talorchestia brito Stebbing (Amphipoda, Talitridae) notes on distribution, taxonomy and biology. Sarsia, 42, 83-96.

Van Senus, P. (1988), Reproduction of the sandhopper, Talorchestia capesis (Dana) (Amphipoda, Talitridae). Crustaceana, 55, 93-103. 
Van Senus, P. and McLachlan, A. (1986), Growth, production and a partial energy budget for the amphipod, Talorchestia capensis (Crustacea: Talitridae) in the Eastern Cape, South Africa. Pubblicazioni della Stazione Zoologica di Napoli I: Mar. Ecol., 7, 165-179.

Watt, P. J. (1994), Parental control of sex ratio in Gammarus duebeni, an organism with environmental sex determination. J. Evol. Biol., 7, 177-187.

Wenner, A. M. (1972), Sex ratio as a function of size in marine Crustacea. Am. Nat., 106, 321-350.

Weslawski, J. M.; Kupidura, T. and Zabicki, M. (2000), Sandhopper, Talitrus saltator (Montagu, 1808) (Amphipoda, Gammaridea), at the Polish Baltic coast: seasonal and spatial distribution patterns. Crustaceana, 73, 961-969.
Wildish, D. J. (1988), Ecology and natural history of aquatic Talitroidea. Canad. J. Zool., 62, 1027-1033.

Williams, J. A. (1978), The annual pattern of reproduction of Talitrus saltator (Crustacea: Amphipoda: Talitridae). J. Zool. London, 184, 231244.

Williams, J. A. (1995), Burrow-zone distribution of the supralittoral amphipod Talitrus saltator on Derbyhaven beach, Isle of Man a possible mechanism for regulating desiccation stress? J. Crustac. Biol., 15, 466-475.
Received: June 09, 2006; Revised: March 02, 2007; Accepted: August 18, 2008 